\title{
The Hepatotoxic and Nephrotoxic Effects of Purwoceng (Pimpinella pruatian Molk.) Roots Ethanol Extract Administration in Subchronic Dose
}

\author{
Fitranto Arjadi i*, Nur Signa Aini Gumilas², Ika Murti Harinii ${ }^{2}$, Vitasari Indriani ${ }^{3}$, Lantip Rujito ${ }^{4}$
}

\begin{abstract}
'Deparment of Anatomy, Faculty of Medicine, Universitas Jenderal Soedirman, Purwokerto, Indonesia ${ }^{2}$ Department of Histology, Faculty of Medicine, Universitas Jenderal Soedirman, Purwokerto, Indonesia

${ }^{3}$ Department of Clinical Pathology, Faculty of Medicine, Universitas Jenderal Soedirman, Purwokerto, Indonesia

${ }^{4}$ Department of Molecular Biology, Faculty of Medicine, Universitas Jenderal Soedirman, Purwokerto, Indonesia
\end{abstract}

Corresponding author email : fitranto.arjadi@unsoed.ac.id

Received November 15, 2020; Accepted May 20, 2021; Available online July 20, 2021

\begin{abstract}
Purwoceng (Pimpinella pruatjan Molk) is an original Indonesian herb which is known to have an aphrodisiac effect. The active compounds in Purwoceng potentially have hepatotoxic and nephrotoxic effects. This study was aimed to analyze the effect of subchronic administration of Purwoceng roots ethanol extract to Wistar Strain of Rattus norvegicus rats. The method of this subchronic toxicity study was an experimental post test only with control group design. Forty male Rattus norvegicus were randomly divided into four groups and get 28-days treatment. Group $A$ as control received aquadest and $1 \%$ CMC (carboxymethyl cellulose), group B, C, and D were given Purwoceng roots ethanol extract of 42, 84, and 168 $\mathrm{mg} / \mathrm{KgBW} /$ day and $1 \% \mathrm{CMC}$. Parameters tested were the levels of urea, creatinine, SGPT (serum glutamic pyruvic transaminase), SGOT (serum oxaloacetic pyruvic transaminase), kidney and hepar histopatology. The results showed a statistically significant for the liver histopathological in group B, creatinine, urea, and kidney histopathology in group C. Our study concluded that subchronic administration of Purwoceng (Pimpinella pruatian Molk) roots ethanol extract could induce hepatotoxicity at the $42 \mathrm{mg} / \mathrm{KgBW} /$ day dose level and nephrotoxicity at the $84 \mathrm{mg} / \mathrm{KgBW} /$ day dose level.
\end{abstract}

Keywords: hepatotoxicity, nephrotoxicity, purwoceng, subchronic toxicity test,

\section{INTRODUCTION}

One of the traditional medicines in Indonesia is Purwoceng (Pimpinella pruatian Molk), especially their roots, which are efficacious as aphrodisiacs (increasing sexual arousal and causing erections), diuretics (accelerate urine flow), and tonics (increasing stamina) (Wahyuningrum, Utami, Dhani, Kumalasari, \& Kusumawardani, 2016). To determine the level of safety and development of traditional drugs, it is necessary to carry out a gradual toxicity test including acute oral toxicity, subchronic oral toxicity and chronic oral toxicity. Acute toxicity test was done and concluded that the hepar and kidney histological appearance, transaminase enzyme of hepar, blood urea and creatinine not significantly affected by acute administration of Purwoceng roots in various doses so there was no acute toxicity in rat at the close up to 2g/kgBW (Arjadi, Kurniawan, Wibowo, Siswandari, \& Rujito, 2019).

Hepar as the primary organ of drug biodegradation and kidney as primary organ of filtration will be exposed to the residual metabolic and toxins that are susceptible to damage. Purwoceng contains substances such as alkaloids, flavonoids, saponins, and tannins which are lipophilic can cause damage hepatocytes and the renal cell membrane (Purwestri, Kartikasari, Putri, Wilson, \& Sembiring, 2016). The other active substances as stigmasterol and sitosterol is known to increase blood urea nitrogen $(25.23 \pm 0.81$ to $35.42 \pm 1.83)$ and creatinine levels $(0.65 \pm 0.01$ to $0.67 \pm 0.02)$ through the mechanism of renal tubular toxicity (Somsak, Peerawit, \& Chusri, 2016). The researcher was interested to conducting a subchronic toxicity test to determine the effect of purwoceng roots ethanol extract (Pimpinella puartian Molk.) on the levels of hepar function test (SGOT, SGPT), kidneys function test (urea, creatinine), kidneys and liver histopathology of white male rats (Rattus norvegicus). The subacute toxicity test is to determine the toxic effect of repeated doses which is not seen in the acute toxicity test and to find a dose that does not cause a toxic effect in subacute administration.

\section{EXPERIMENTAL SECTION}

All procedures in this study were approved by the Medical Research Ethics Committee of the Faculty of 
Medicine, Jenderal Soedirman University (Ethical approval Ref: 139/KEPK/VI/2019). The method used was an experimental method with a post-test only with group control trial approach. The minimum sample size for the subchronic toxicity test is 40 samples, according to the OECD guidelines (OECD 407, 2008). The experimental animals were then divided evenly into four different groups using the completely randomized design (CRD) method. Before being treated, the experimental animals were acclimatized for seven days. Each of the five experimental animals was placed in a glass cage sized $60 \times 30 \times 30 \mathrm{~cm}$ from the beginning of acclimatization until the end of the treatment. Group $A$ is the control group with giving aquades and $C M C 1 \%$, group $B, C$ and $D$ are groups with the administration of Purwoceng roots ethanol extract $42 \mathrm{mg} / \mathrm{kgBW} /$ day, $84 \mathrm{mg} / \mathrm{kgBW} /$ day and 168 $\mathrm{mg} / \mathrm{kgBW} /$ day (Arjadi et al., 2019). Treatment was given per oral using a $1.5 \mathrm{cc}$ gastric sonde at the time of 11.00-12.00 every day for 28 days.

The experimental animals used in this study were male white rat Wistar strain (Rattus norvegicus) obtained from UD Wistar Ltd., Yogyakarta. Experimental animals were selected with an age range of 6-8 weeks, have weight 100-150 g, healthy, and did not have an increase or decrease in body weight $\geq 20 \%$ during acclimatization. Experimental animals are conditioned in a room temperature of $22^{\circ} \mathrm{C}( \pm 3$ $\left.{ }^{\circ} \mathrm{C}\right), 12$ hours of bright lighting and 12 hours of darkness, feed and drink must be provided in ad libitum (OECD, 2008). The whole series of research was conducted at Animal House, Medical Faculty of Jenderal Soedirman University. The blood and organ sampling from experimental animals was carried out on the 36th day of treatment, after 8 days of acclimatization and 28 days of intervention and measurement of SGOT and SGPT levels using UV test method, urea level using urease-GLDH method $(\lambda 340$ $\mathrm{nm})$ while measurement of creatinine with Jaffe method $(\lambda 492 \mathrm{~nm}$ ) and data was obtained after intervention. Hepar histological appearance were counted based on a Modified Roenigk score ( $1=$ normal cells, 2 = parenchymatous degeneration cells, 3 = hydropic degeneration cells, $4=$ necrotizing cells) of 20 hepatocytes per field of view and total score summed up to five fields of view every group. The proximal tubules of kidney were observed in 100 cells and scoring 0 for a normal histological appearance, a score 1 for tubular cell degeneration with necrosis, score 2 for necrosis $\leq 25 \%$, score 3 for necrosis $26-50 \%$, score 4 for necrosis $51-75 \%$, and a score of 5 for necrosis $>75 \%$.

Qualitative data were analyzed with univariate analysis that consists of the mean and standard deviation of observations each group. Validity and reliability test for examine histological appearance between observers were done using the Kappa test. The quantitative data were analysed by the ShapiroWilk test for the data normality, the homogeneity test of the data using the Levene test and the data were analyzed using the One-Way ANOVA test.

\section{RESULTS AND DISCUSSION}

Table 1 and 2 show the results of univariate analysis of levels of SGPT, SGOT, urea and creatinine. Bivariate analysis of the One-Way ANOVA tests on SGPT and SGOT parameters showed no statistically significant differences with a value of $p=0.454$ for SGPT levels and $p=0.162$ for SGOT levels. Bivariate analysis test resulted in a value of $p=0.034$ on urea levels and $p=0.001$ at creatinine levels that shows that there are significant differences in at least two groups of data, both on urea and creatinine levels.

Table 1. SGPT and SGOT levels of experimental animals

\begin{tabular}{cccccccc}
\hline & \multirow{4}{c}{ SGPT (IU/I) } & \multicolumn{3}{c}{ SGOT (IU/I) } \\
& $N$ & Min. & Max. & Mean \pm SD & Min. & Max. & Mean \pm SD \\
\hline Group A & 10 & 96 & 167 & $125.1 \pm 24.2$ & 56 & 93 & $73.6 \pm 12$ \\
Group B & 10 & 117 & 242 & $162.0 \pm 39$ & 62 & 99 & $80.9 \pm 12.1$ \\
Group C & 9 & 94 & 293 & $175.3 \pm 72.5$ & 68 & 131 & $89.6 \pm 24.8$ \\
Group D & 10 & 108 & 313 & $168.2 \pm 67.6$ & 73 & 133 & $85.4 \pm 17.9$ \\
\hline
\end{tabular}

Notes: Min=minimum, Max=maximum, Reference value of SGOT $=72.9-127.9 \mathrm{IU} / \mathrm{L}$, Reference value of SGPT $=44.5-74.9 \mathrm{IU} / \mathrm{L}$

Table 2. Urea and creatinine levels of experimental animals

\begin{tabular}{cccccccc}
\hline & \multirow{2}{*}{$\mathrm{N}$} & \multicolumn{3}{c}{ Urea $(\mathrm{mg} / \mathrm{dL})$} & \multicolumn{3}{c}{ Creatinine $(\mathrm{mg} / \mathrm{dL})$} \\
& & Min. & Max & Mean $\pm \mathrm{SD}$ & Min. & Max & Mean $\pm \mathrm{SD}$ \\
\hline Group A & 10 & 21 & 44 & $30.40 \pm 8.09$ & 0.44 & 0.79 & $0.57 \pm 0.12$ \\
Group B & 10 & 27 & 58 & $36.80 \pm 9.05$ & 0.28 & 0.61 & $0.42 \pm 0.09$ \\
Group C & 10 & 27 & 53 & $39.20 \pm 7.99$ & 0.35 & 0.55 & $0.43 \pm 0.06$ \\
Group D & 10 & 24 & 47 & $30.60 \pm 5.73$ & 0.36 & 0.50 & $0.41 \pm 0.04$ \\
\hline
\end{tabular}

Notes: Median $=$ middle value, Mean $=$ average, $\mathrm{SD}=$ standard deviation, Min $=$ minimum, Max $=$ maximum, Reference value of Urea $=15-21 \mathrm{mg} / \mathrm{dL}$, Reference value of creatinine $=$ $0.2-0.8 \mathrm{mg} / \mathrm{dL}$ 

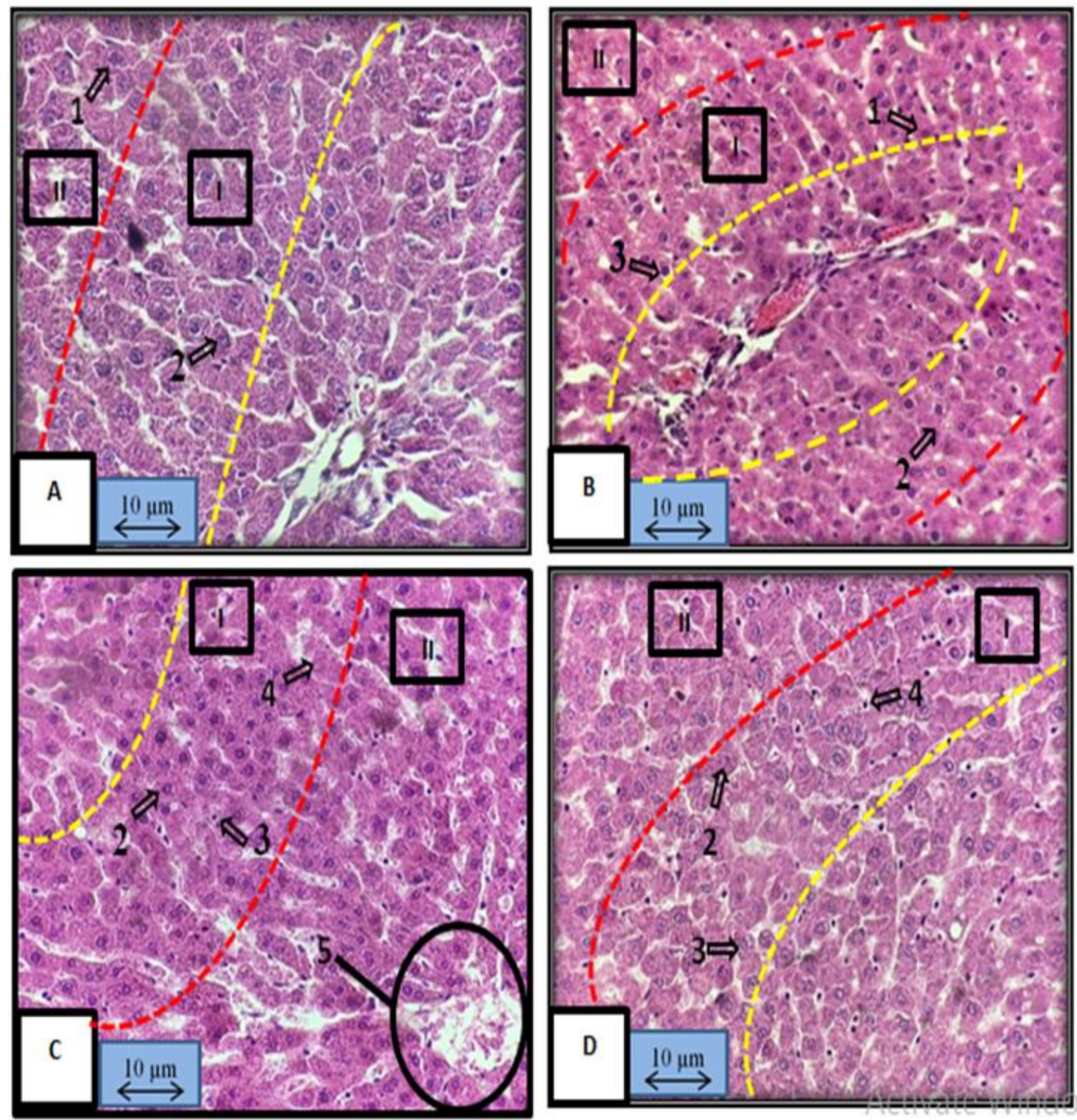

Figure 1. Histology of rat liver after treatment (Hematoxylin-Eosin, $400 \mathrm{X}$ magnification) Note : (A) Healthy control group, single dose treatment group of purwoceng roots ethanol extract (B) 42 $\mathrm{mg} / \mathrm{kgBW}$, (C) $84 \mathrm{mg} / \mathrm{kgBW}$, (D) $168 \mathrm{mg} / \mathrm{kgBW}$. (1) normal hepatocytes; (2) parenchymatic degeneration; (3) hydropic degeneration; (4) necrosis; (5) central veins; yellow arrow) hear zone 1; (red arrow) hepar zone 2

Table 3. Mean of normal hepatocytes and damaged hepatocytes based on Roenigk scoring (Source: Researcher's primary data)

\begin{tabular}{lllll}
\hline & $\begin{array}{l}\text { Normal } \\
\text { Hepatocytes } \\
(\text { Mean } \pm \text { SD) }\end{array}$ & $\begin{array}{l}\text { Parenchymatic } \\
\text { Degeneration } \\
(\text { Mean } \pm \text { SD) }\end{array}$ & $\begin{array}{l}\text { Hydropic } \\
\text { Degeneration } \\
(\text { Mean } \pm \text { SD) }\end{array}$ & $\begin{array}{l}\text { Necrosis } \\
\text { (Mean } \pm \text { SD) }\end{array}$ \\
\hline A & $53.30 \pm 20.17$ & $51.40 \pm 17.18$ & $49.20 \pm 25.11$ & $18.40 \pm 21.84$ \\
B & $16.90 \pm 13.43$ & $66.80 \pm 18.77$ & $85.50 \pm 27.55$ & $78.20 \pm 58.49$ \\
C & $13.00 \pm 12.49$ & $62.60 \pm 33.65$ & $79.10 \pm 62.22$ & $104.0 \pm 45.45$ \\
D & $2.40 \pm 2.63$ & $59.00 \pm 23.41$ & $82.80 \pm 34.62$ & $157.9 \pm 44.67$ \\
\hline
\end{tabular}




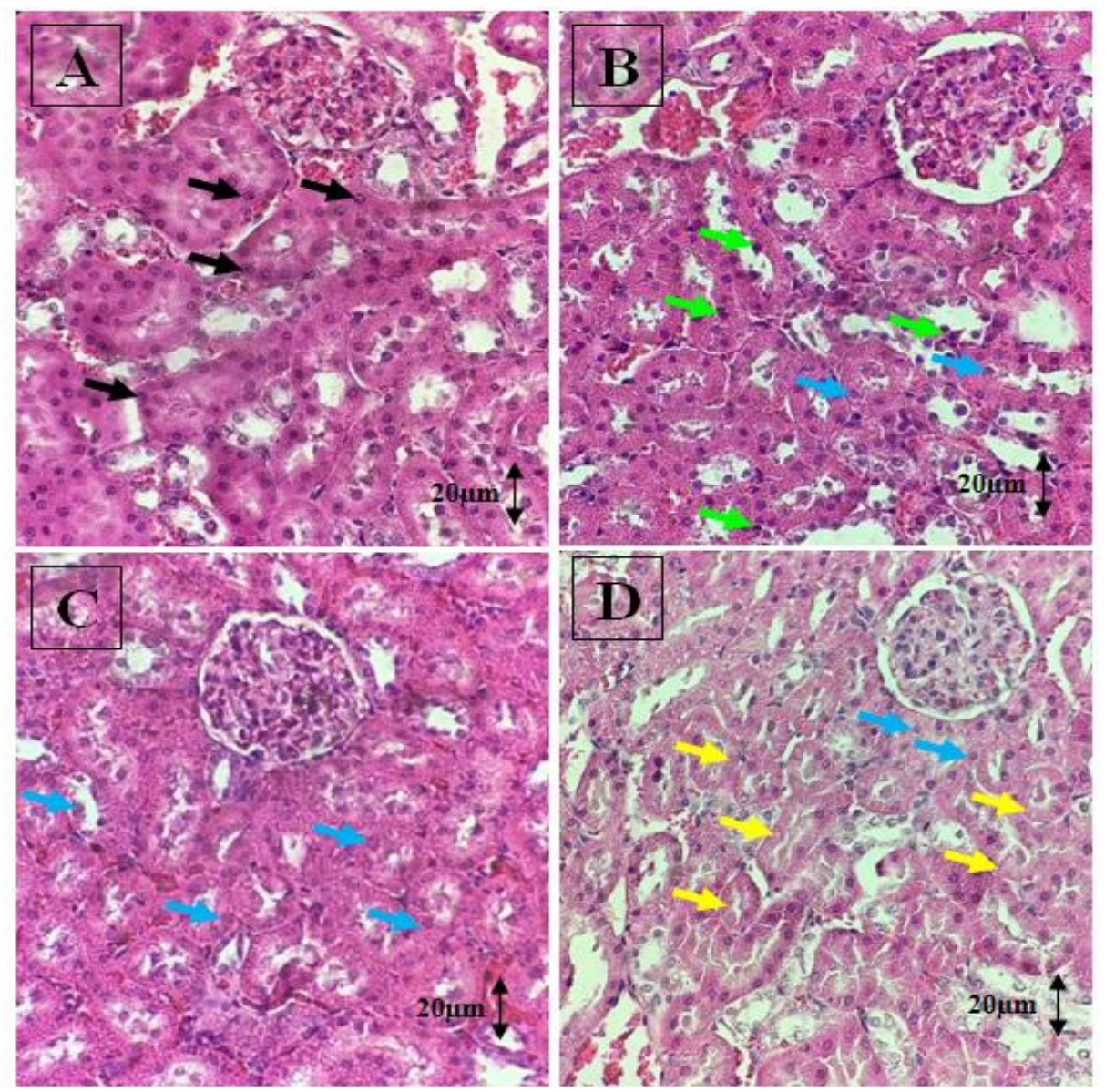

Figure 2. Histology of Proximal Tubules (Hematoxylin-Eosin, $400 \mathrm{X}$ magnification) (A) is group $\mathrm{A}$ (control) which shows the proximal tubular cells with normal nuclei (black arrows); (B) is group B (purwoceng roots ethanol extract $42 \mathrm{mg} / \mathrm{kgBW} /$ day) obtained the picnosis core (green arrow) and karyorexis (blue arrow); (C) is group C (84 mg / kgBW / day purwoceng roots ethanol extract) obtained the karyorexis core (blue arrow); (D) is group D (ethanol extract of purwoceng roots $168 \mathrm{mg} / \mathrm{kgBW} /$ day), not only found the core of karyorexis (blue arrow), also found cariolysis (yellow arrow)

Table 4. Mean Score of Proximal Tubular Necrosis in Experimental Animals

\begin{tabular}{cc}
\hline \multicolumn{1}{c}{ Groups } & $\begin{array}{c}\text { Necrosis Score } \\
\text { (Mean } \pm \text { SD) }\end{array}$ \\
\hline A (aquades per oral $1-2 \mathrm{~mL} / 100 \mathrm{gramBW})$ & $1.90 \pm 0.32$ \\
B (Purwoceng roots extract $42 \mathrm{mg} / \mathrm{kgBW} /$ day) & $2.20 \pm 0.42 \#$ \\
C (purwoceng roots extract $84 \mathrm{mg} / \mathrm{kgBW} /$ day) & $3.50 \pm 1.27^{*}$ \\
D (purwoceng roots extract $168 \mathrm{mg} / \mathrm{kgBW} /$ day) & $4.50 \pm 0.53 *$ \\
\hline
\end{tabular}

Notes: $\left(^{*}\right)$ : significantly different from group A $(p<0.05 ;$ Mann-Whitney); (\#): significantly different from groups $C$ and $D(p<0.05$; Mann-Whitney)

Parameters of SGOT and SGPT levels, both of which do not show a significant increase between treatment groups. However, when compared with the reference values of SGOT and SGPT levels in group A as controls, they are in the normal range, while in groups B, C, and D gave Purwoceng various doses showed levels are above the reference value. It shows the potential for hepatotoxicity in the subchronic administration of Purwoceng roots ethanol extract. The existence of compounds such as tannins and alkaloids in Purwoceng which are lipophilic make it easy to bind to the cell wall and then damage the cell wall by reducing its permeability (Purwita, Indah, \& Trimulyono, 2013). Membrane permeability impairment triggers the release of enzymes in hepatocytes, such as SGOT and mainly SGPT, into the bloodstream. Phenol compounds, flavonoids, cytosterol, pheladren, furanocumarin, hydroquinone and tannins in Purwoceng can be antioxidants in effective exposure but in the number of doses or long periods of excess exposure these compounds will turn into prooxidant may induce lipid peroxidation, DNA damage, mutagenetic dan apoptotic normal cell (Eghbaliferiz, \& Iranshahi, 2016). Balance disruption 
of antioxidant then induces the formation of reactive oxygen species (ROS). Accumulation of ROS results in inhibition of mitochondrial function, one of which is marked by an increase in SGOT, in the next stage oxidative stress can occur (Chouchani et al., 2014).

Based on Figure 1, changes in hepatocyte histology are seen in all treatment groups. Histology shows that group A (healthy control) has found normal hepatocytes; some have degeneration. Groups B and $C$ are found mainly in hydropic and parenchymatic degeneration. Group D is mostly found cells necrosis. This is in line with the data in Table 3 which shows that the higher the dose of Purwoceng roots ethanol extract, the more severe damage caused. Hepatocytes with abnormalities can be caused by several factors such as biological factors, chemical factors, hereditary factors, and environmental factors. Biological factors can affect the damage to the liver image associated with the presence of microorganisms in the form of fungi in the feed given (Yang et al., 2017). There is a group of fungi that live in experimental animal feed and produce aflatoxin which a substance that can cause damage to the liver (Liu, Chang, Marsh, \& Wu, 2012).

The mean Roenigk total score in Table 3 can be seen highest in group D with a mean of $302.1 \pm$ 23.26, while the mean Roenigk total score is lowest in group $A$ with a mean of $172.3 \pm 37.58$. Group $B$ and $C$ are between groups $A$ and $D$. The mean group $B$ is $247.4 \pm 42.47$, while the mean of group $C$ has a higher mean of $258.7 \pm 42.52$. It is consistent with the concept of the relationship between concentration and response at certain doses; the concentration of receptors can have a therapeutic effect, but can also cause toxic effects. It look like that the higher the concentration, the greater the response (Dahl et al., 2013).

In the value of urine biochemical parameter, the control group exceeding the normal range because the extraction process using $96 \%$ alcohol solvent that resulted in a higher content of Purwoceng root active ingredients, including nephrotoxicity compound, for example stigmasterol. The results obtained from this study indicate a significant increase in urea levels in groups B and C. Increased urea levels can be caused by toxic effects on the renal tubules, renal parenchyma, heart disease, and blockage of urine flow because there are crystals in the urine, calculus, and also other types of blockages (Hor et al., 2012). The increasing of blood urea levels can also come from free radicals, through the mechanism of renal tubular toxicity (Nisha, Srinivasa, Thanga, \& Jagatha, 2017). Administration of ethanol extract in high doses in group $D$ actually has lower urea levels than group $B$ and $C$. In general, the principle that causes this phenomenon has not been known yet, but it can be caused by the different mechanism of how the various active compounds contained at certain dosage levels (Batshaw, Macarthur, \& Thurman, 2001).
Serum creatinine is the result of creatinine phosphate catabolism in skeletal muscles. Creatinine levels are considered more specific as an indicator of decreased nephron function compared to an increase in urea because creatinine metabolites are fully excreted in urine through glomerular filtration (Peng, Zhang, \& Zhou, 2016). Meanwhile, about $50 \%$ of kidney function has decreased before urea levels increases. Decreased creatinine levels can also occur due to a decrease in muscle mass (Hor et al., 2012). Creatinine levels in this study decreased in groups B, $C$, and D when compared with the control group.

Purwoceng roots ethanol extract contains flavonoids and tannins, the lipophilic compounds that are difficult to excrete in the kidneys so that if given for a long time, they will accumulate in the proximal tubule. These compounds are lipophilic compounds that are difficult to excrete in the kidneys so that if given for a long time, they will accumulate in the proximal tubule. Lipophilic compound requires enzymatic conversion into hydrophilic before being xcreeted in the urine and more lipophilic a compound is, the more difficult it becomes for excretion via the kidney (Setiawan, \& Rahardjo, 2016). The proximal tubule is very sensitive to toxic substances; if the proximal tubule cannot adapt to these conditions, it will cause irreversible injury in the form of necrosis (Cardenas, \& Ginès, 2017). Group B has not statistically experienced a toxic effect in the form of proximal tubular necrosis, while groups $C$ and D have experienced the toxic effects of purwoceng roots in the form of proximal tubular necrosis. It indicates that the increased dose of purwoceng roots ethanol extract further increases the score of proximal renal tubular necrosis in experimental animals.

As well as the levels of urea and creatinine on the histopathological appearance of the proximal tubule of the kidney, SGOT and SGPT are enzymes present in hepatocytes and are released into the blood stream in response to hepatocyte injury or death but non linear may occur between the alteration of biochemical parameter with response. The decrease in the effect at higher doses shows that there has been a saturated reaction between drug molecules and their receptors so that increasing the dose will not cause an increase in the effects that arise (Katzung, 2012). Limitations of this study include not conducting a thoroughly animal health examination at the beginning of the study. Measurement of creatinine, urea, SGOT, and SGPT levels before treatment was also not carried out, because feared could lead to an increased risk of morbidity and mortality in experimental animals.

\section{CONCLUSION}

The kidney would be damaged at a dose of 84 $\mathrm{mg} / \mathrm{KgBB} /$ day and liver at a dose of $42 \mathrm{mg} / \mathrm{KgBB} /$ day, it can be concluded that subchronic administration of the Purwoceng roots ethanol extract shows to have 
nephrotoxic and hepatotoxic effects on Wistar strain male white rats. It is relatively safe to consume Purwoceng roots ethanol extract as tradisional herbs because it has hepatotoxicity dan nephrotoxocity at low doses but we still need requires further research by measuring chronic toxicity to determine the effect of toxicity on repeated chronic administration.

\section{ACKNOWLEDGMENTS}

We wish to express our gratitude to Research and Community Services Center of Jenderal Soedirman University for the grant and all parties who directly or indirectly assisted in the preparation and implementation of this research.

\section{REFERENCES}

Arjadi, F., Kurniawan, D. W., Wibowo, Y., Siswandari, W., \& Rujito, L. (2019). No acute toxicity tests of Purwoceng (Pimpinella pruatian Molk.) ethanolic extract on male albino rat by determined hepatorenal function test and histopathology. Molekul, 14(2), 117-125.

Batshaw, M. L., Macarthur, R. B., \& Tuchman, M. (2001). Alternative pathway therapy for urea cycle disorders: Twenty years later. Journal of Pediatrics. $138 \quad$ (1 $\quad$ Suppl), S46-54 https://doi.org/10.1067/mpd.2001.111836 https://doi.org/10.1067/mpd.2001.111836

Cardenas, A., \& Ginès, P. (2017). Hepatorenal syndrome. In Handbook of liver disease. https://doi.org/10.1016/B978-0-323-478748.00014-6

Chouchani, E. T., Pell, V. R., Gaude, E., Aksentijević, D., Sundier, S. Y., Robb, E. L., Logan, A., Nadtochiy, S. M., Ord, E. N. J., Smith, A. C., Eyassu, F., Shirley, R., Hu, C. H., Dare, A. J., James, A. M., Rogatti, S., Hartley, R. C., Eaton, S., Costa, A. S. H., ... Murphy, M. P. (2014). Ischaemic accumulation of succinate controls reperfusion injury through mitochondrial ROS. Nature. 515 (7527), 431-435 https://doi.org/10.1038/nature13909

Dahl, R. H., Zhang, F., Alonso-Gutierrez, J., Baidoo, E., Batth, T. S., Redding-Johanson, A. M., Petzold, C. J., Mukhopadhyay, A., Lee, T. S., Adams, P. D., \& Keasling, J. D. (2013). Engineering dynamic pathway regulation using stress-response promoters. Nature Biotechnology. 31,1039-1046. https://doi.org/10.1038/nbt.2689

Eghbaliferiz, S., \& Iranshahi, M. (2016). Prooxidant activity of folyphenols, flavonoids, anthocyanins and carotenoids: Updated review of mechanisms and catalyzing metals. Phytotherapy Research, 30(9), 1-14. https://doi.org/10.1002/ptr.5643

Hor, S. Y., Ahmad, M., Farsi, E., Yam, M. F., Hashim, M. A., Lim, C. P., Sadikun, A., \& Asmawi, M. Z. (2012). Safety assessment of methanol extract of red dragon fruit (Hylocereus polyrhizus): Acute and subchronic toxicity studies. Regulatory Toxicology and Pharmacology, 63(1), 106-114. https://doi.org/10.1016/ i.yrtph.2012.03.006

Katzung, B. M. (2012). Farmakologi dasar dan klinik (Basic and clinical pharmacology). 6ed. EGC.

Liv, Y., Chang, C. C. H., Marsh, G. M., \& Wu, F. (2012). Population attributable risk of aflatoxinrelated liver cancer: Systematic review and meta-analysis. European Journal of Cancer. 48(14), 2125-36. https://doi.org/10.1016/ j.ejca.2012.02.009

Nisha, R., Srinivasa, K. S. R., Thanga, M. K., \& Jagatha, P. (2017). Biochemical evaluation of creatinine and urea in patients with renal failure undergoing hemodialysis. Journal of Clinical Pathology and Laboratory Medicine. 1(2):1-5

OECD 407. (2008). Guideline for the testing of chemicals test No. 407: Repeated dose 28-day oral toxicity study in rodents. In Organization For Economic Cooperation And Development. https://doi.org/10.1787/9789264070684-en

Peng, K. Z., Zhang, S. Y., \& Zhou, H. L. (2016). Toxicological evaluation of the flavonoid-rich extract from Maydis stigma: Subchronic toxicity and genotoxicity studies in mice. Journal of Ethnopharmacology. 192:161-169. https://doi.org/10.1016/i.jep.2016.07.012

Purwestri, Y. A., Kartikasari, N., Putri, S. G., Wilson, W., \& Sembiring, L. (2016). Metabolic profiling of endophytic bacteria from Purwoceng (Pimpinella pruatian Molkend) root and antibacterial activity against Staphylococcus aureus and Pseudomonas aeruginosa. AIP Conference https://doi.org/10.1063/1.4953537

Purwita, A. A., Indah, N. K., \& Trimulyono, G. (2013). Penggunaan ekstrak daun srikaya (Annona squamosa) sebagai pengendali jamur Fusarium oxysporum secara in vitro (The use of srikaya leaf extract as an in vitro fungus control for Fusarium oxysporum). LenteraBio. 2(2),179-183

Setiawan, S., \& Rahardjo, M. (2016 Respon pemupukan terhadap pertumbuhan, produksi dan mutu herba meniran (Phyllantus niruri) (Fertilization response to growth, production and quality of meniran herbs). Buletin Penelitian Tanaman Rempah dan Obat, 26(1), 25-34 https://doi.org/10.21082/bullittro. v26n1.2015.25-34

Somsak, N., Peerawit, P., \& Chusri, T. (2016). Hypoglycemic activity in diabetic rats of stigmasterol and sitosterol-3-O--Dglucopyranoside isolated from Pseuderanthemum palatiferum (Nees) Radlk. leaf extract. Journal of Medicinal Plants Research. 9(20), 629-635. https://doi.org/10.5897/jmpr2014.5722 
Wahyuningrum, R., Utami, P. I., Dhiani, B. A., Kumalasari, M., \& Kusumawardani, R. S. (2016). Screening of potential free radicals scavenger and antibacterial activities of Purwoceng (Pimpinella alpina Molk). Tropical Life Sciences Research, 27(supp1), 161-166. https://doi.org/10.21315/tlsr2016.27.3.22

Yang, A. M., Inamine, T., Hochrath, K., Chen, P., Wang, L., Llorente, C., Bluemel, S., Hartmann,
P., Xu, J., Koyama, Y., Kisseleva, T., Torralba, M. G., Moncera, K., Beeri, K., Chen, C. S., Freese, K., Hellerbrand, C., Lee, S. M. L., Hoffman, H. M., ... Schnabl, B. (2017). Intestinal fungi contribute to development of alcoholic liver disease. Journal of Clinical Investigation. 127(7),2829-2841. https://doi.org/10.1172/JCI90562 